\title{
Potential of Alternative Sources for Electric Power Generation in the State of Paraná
}

\author{
Diego Rodrigues Pessoa ${ }^{\text {* }}$ \\ https://orcid.org/0000-0003-2970-1874 \\ Débora Cristina Colla ${ }^{1}$ \\ https://orcid.org/0000-0001-6954-9016
}

\section{Bill Jorge Costa ${ }^{1}$ \\ https://orcid.org/0000-0002-5768-7865}

${ }^{1}$ Paraná Institute of Technology (TECPAR), Technological Information Center, Curitiba, Paraná, Brazil;

Editor-in-Chief: Alexandre Rasi Aoki

Associate Editor: Alexandre Rasi Aoki

Received: 2020.11.20; Accepted: 2021.06.02.

*Correspondence: dirpessoa@gmail.com; Tel: +5541999407777 (D.R.P.)

\section{HIGHLIGHTS}

- Realistic estimates of alternative energy sources at municipal levels

- Use of business analytics tools to present and predict source potentials

- Distributed generation viability

\begin{abstract}
The State of Paraná stands out in Brazil for its hydraulic potential for electricity generation. Furthermore, the State also shows potential for the use of other sources of energy, such as solar energy, biogas and biomass. The study traces the profile of electric energy consumption and compiles analysis of the alternative energy potentials of Paraná on the use of solar energy, the biomass of forest residues and agricultural crops, the generation of biogas through the residues of farmed animals and the urban solids residues. The work took account for the estimates, the logistical limitations for the biomass or biogas collection and the real availability of the wastes in terms of viability of exploration through distributed generation plants. The use of the business analytics software Tableau Desktop 2020.3.2® made possible the open data analysis at the municipal level. The paper provides realistic estimates about the feasibility of the use of alternative energy sources in the State of Paraná.
\end{abstract}

Keywords: Renewable Energy Sources; Potential of Energy Generation Estimate; Open Data Analysis; Distributed Energy Generation; State of Paraná.

\section{INTRODUCTION}

Hydropower is the main source of renewable energy in Brazil. The country began to use water from the rivers to generate electric power in 1883, when the hydroelectric plant of Ribeirão do Inferno, in Diamantina, Minas Gerais began operating [1]. The first hydroelectric plant of Paraná, Serra da Prata Power Plant, near Paranaguá, inaugurated in 1910 with a power of 400 kVA supplied electricity to the town until the beginning 
of the '70s. The unit has been discontinued after such period [2]. After just over 100 years, the installed generation capacity of the State is over $16,000 \mathrm{MW}$ [3].

Itaipu, the largest hydroelectric power plant in Brazil is in the State of Paraná. According to Itaipu Binacional [4], the Itaipu hydroelectric power plant has 14,000 MW of installed capacity and provides around $11.3 \%$ of the energy consumed in Brazil and $88.1 \%$ of the energy consumed in Paraguay. Such a highlight for hydroelectric power is due mainly to the vast hydro potential existing in the State and the competitiveness of that source. However, the diversity of the energy matrix is essential to ensure greater flexibility in meeting future demands and greater robustness and security of the electric supply system.

So, Paraná State still shows great potential for using other energy sources such as solar energy and biomass energy (bioenergy), which focus on the use of agricultural and forestry wastes, considering the size of agricultural and forestry activities of Paraná. This paper presents a brief analysis of the solar exploration potential, but focus on the estimates of the agricultural and forestry biofuels potentials due to the cited economic activities of the State. We target to mobilize the State and society abilities, aiming to develop new skills for the energy, economic, environmental and social sectors in Paraná.

Because of this privileged condition, the Center of Technological Information of Tecpar elaborated the production of renewable energy estimates in the State, based on a preliminary Tecpar study on the subject, as requested by the State Government through the Smart Energy Program in 2018. However, data here discussed refer to 2019 consolidated figures.

\section{METHODOLOGY}

This study is based on an analysis of the open data on profiles of electricity consumption and energy potential of biomass and biogas in the State of Paraná. Data explored and analyzed are related to the consumed electricity in the economic sectors of Paraná, the paddy rice and cassava productions, the wood extraction for industry, the numbers for the livestock of chicken, swine and milking cows and finally the estimated and census population for each municipality of Paraná. The primary source for all these data is the Brazilian Institute of Geography and Statistics (IBGE) [5]. However, the Paraná Institute for Economic Development (IPARDES) [6] website was the main online data portal used to access the open data from IBGE.

The work compiles all the data in annual basis up to the year of 2019. We extracted, treated, loaded and analyzed the data and built the graphics, maps and statistical predictions using Tableau Desktop 2020.3.2® business analytics (BA) tool. We calculated the conversions of wastes production into potential of energy generation through embedded calculated fields in the software. An exponential smoothing method embedded in the BA tool generated the predictions, based on historical data series. This method finds a regular pattern or a seasonality in the measures and attempts to extrapolate such behavior into the future. The forecasts shown here do not disregard any period of the data series and consider a $95 \%$ confidence level.

The work estimates the capability of exploration of the potentials for each energy source in terms of viability of hypothetical distributed generation plants. According to the Brazilian Electricity Regulatory Agency (ANEEL) Normative Resolution No.482 of April 17, 2012, a distributed microgeneration plant of renewable energy sources is defined as the generating plant with an installed power capacity of less than $75 \mathrm{~kW}$, while a mini generation plant has an installed power capacity of more than $75 \mathrm{~kW}$ and less than or equal to $5 \mathrm{MW}$. Above that it is called distributed generation (DG) [7]. Based on this definition, it was estimated that the range of energy values generated annually by a mini generation plant would range from 0.657 to $43,800 \mathrm{GWh} /$ year and it was considered that values above this maximum would fall into a category of DG. The method considers a municipality practical for mini or distributed generation when the estimated energy potential for each source, within the territory of this municipality, fits in the bands of the classification criteria defined by ANEEL.

\section{Generation from solar energy}

Data obtained from Pereira and coauthors (2017) [8] present the average daily solar energy incidence per area $\left(\mathrm{Wh} / \mathrm{m}^{2}\right.$.day) for each month of the year of 2017 in each latitude and longitude coordinates. Thus, to estimate the average annual accumulated incidence, the average daily value of the year was multiplied by 365 and divided by 1,000 to get the absolute value of solar energy applied in the year for each geographical point, in $\mathrm{kWh} / \mathrm{m}^{2}$. 
As for the estimations of the potential of solar energy generation in Paraná, we considered the average efficiency of photovoltaic solar panels available in the market as $16 \%$ and arbitrated the performance rate of the system as $80 \%$.

To simplify the estimates of generation potential through solar energy, we divided the territory of Paraná into three bands of average annual solar incidence: in the coastal municipalities (east of the RMC mesoregion), the value of $1,625 \mathrm{kWh} / \mathrm{m}^{2}$ was adopted; for the municipalities in the southeast mesoregion, east of the central eastern mesoregion and west of the RMC, $1,725 \mathrm{kWh} / \mathrm{m}^{2}$ was adopted; for the rest of the municipalities in Paraná, $1,825 \mathrm{kWh} / \mathrm{m}^{2}$ was adopted. The left map of Figure 1 shows the territory of Paraná divided in 3 distinct bands of intensity of solar incidence, represented by the yellow, orange and red colors, clearly separating them.

In order to generate the analysis on the demanded solar capture area per unity of energy consumption, we extracted the data of residential consumption unities from IPARDES [6]. However, the primary source is the Energy Company of Paraná (COPEL), whose database cannot be directly accessed.

\section{Generation from burning biomass of rice hulls}

According to Souza and coauthors [9], each ton of rice produced results $1,315 \mathrm{~kg}$ of straw, with a low heating value of $16.0 \mathrm{MJ} / \mathrm{kg}[10,11]$. The adopted efficiency of burning the straw in a boiler was $50 \%$ [12].

\section{Generation from burning biogas of cassava starch wastewater}

The yield of starch production from cassava is $25 \%$ [13]. The cassava starch conversion factor into manipueira is $0.33 \mathrm{~m}^{3} / \mathrm{t}$ [14] and the factor of conversion of biogas into electricity is $1.43 \mathrm{kWh} / \mathrm{m}^{3}$ [15].

\section{Generation from burning biomass of forestry wastes}

The data on the amount of wood $\left(\mathrm{m}^{3}\right)$ for paper and cellulose production and for other purposes (furniture industry) in the cultivated areas destined for the commercial or industrial sectors came from IPARDES online portal, as collected by IBGE.

In this work we considered a percentage of $15 \%$ of wastes as a result of benefiting trees for the paper and cellulose processing (branches and barks) [16,17]. The average proportion of waste produced at sawmills is around $26 \%$. Approximately $45 \%$ of the waste produced goes to aviary bedding, so only $55 \%$ of these would be available for burning in boilers [18].

The efficiency of burning the residues in biomass boilers adopted was $50 \%$ [12]. An estimate of the average heating value of the wastes was $0.01328 \mathrm{GWh} / \mathrm{m}^{3}$, determined through the values available in ADETEC (2018) [19].

\section{Generation from burning biogas of animal breeding wastes and municipal solid wastes}

Data on the amount of wastes produced per animal unit of different breeds were then extracted from IPARDES online portal, as collected by IBGE. Table 2 shows the estimated conversion factors for biogas $\left(\mathrm{m}^{3}\right)$ generated daily. The work based the estimates on the limits compiled and presented in the 2016 publication of FIEP and SENAI/PR, before mentioned.

Table 1. Parameters of conversion of animal units to biogas volume $\left(\mathrm{m}^{3}\right)$ generated per day.

\begin{tabular}{lcccc}
\hline & Chickens & Swine & Milk cows & Source \\
\hline $\begin{array}{l}\text { Amount of wastes per animal unit per day } \\
{[\mathrm{kg} /(\text { animal unit/day)] }}\end{array}$ & 0.150 & 2.350 & 12.500 & {$[20]$} \\
$\begin{array}{l}\text { Conversion factor of biogas to waste } \\
{\left[\mathrm{m}^{3} / \mathrm{kg}\right]}\end{array}$ & 0.050 & 0.079 & 0.038 & {$[21]$} \\
\hline
\end{tabular}

For the study on the potential of the MW, the average conversion factor of $0.749 \mathrm{~kg}$ of MW per inhabitant per day [22], multiplied by the conversion factor of MW in biogas equals $100 \mathrm{~m}^{3 / t}$ [23]. The conversion factor of biogas in electric energy $\left(\mathrm{kWh} / \mathrm{m}^{3}\right)$ is equal to 1.43 [15]. We arbitrated the efficiency value of the natural gas boiler for the estimated calculations of energy generation as $80 \%$. 


\section{RESULTS AND DISCUSSION}

\section{Solar generation}

In general, Brazil has high levels of solar incidence throughout its territory. In the case of Paraná, even the regions of lower solar incidence (eastern and coastal regions) present a significant generation potential as shown in Figure 1.

It is worth noting that Germany and the United Kingdom, despite having considerably lower levels of solar incidence than those registered in Paraná, invest heavily in such alternative energy and consider it practical in their regions $[24,25]$.
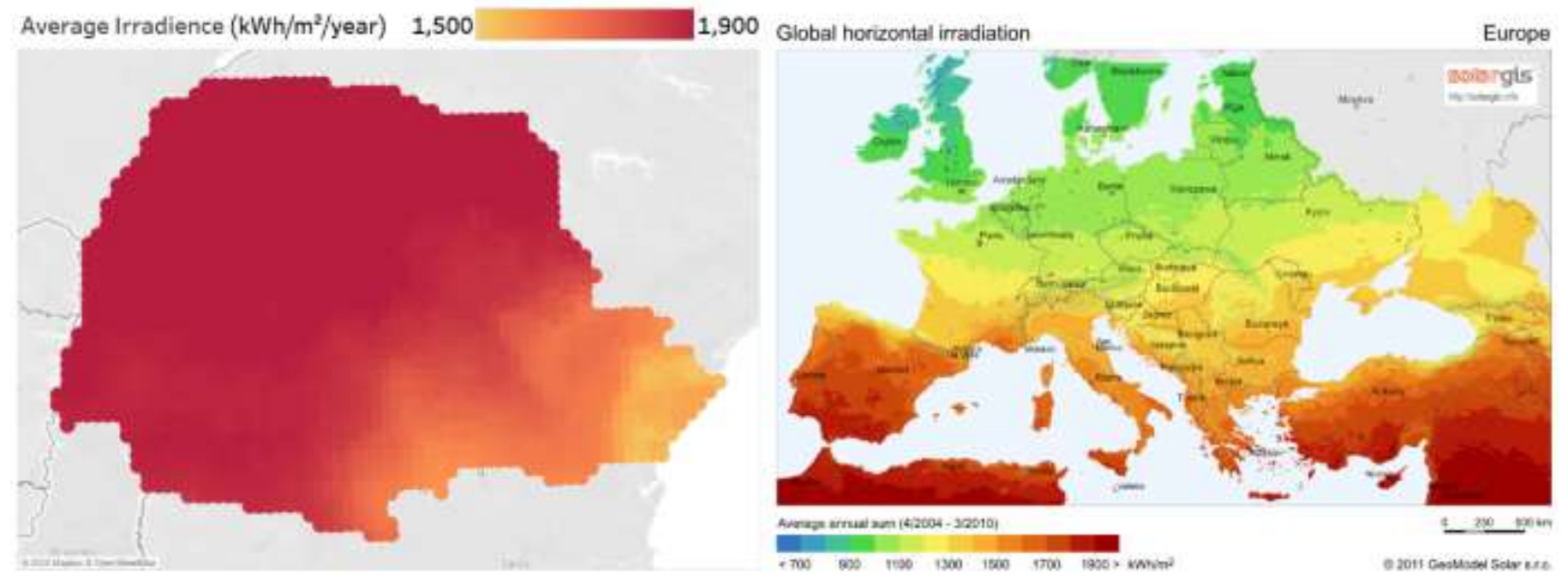

Figure 1. Comparison between the solar incidence in the territory of Paraná and in European territory [26].

Dividing the area covered by photovoltaic panels necessary for the electricity supply of a certain municipality in 2019 by the number of residential unities of energy consumption, we could estimate that the relative area needed per unity is lower than $10 \mathrm{~m}^{2}$ (including the capital Curitiba with $9.4 \mathrm{~m}^{2}$ ) in most of the municipalities of Paraná. The municipalities with the greatest needs of area per inhabitant are Entre Rios do Oeste $\left(12.5 \mathrm{~m}^{2}\right)$, Mercedes $\left(12.0 \mathrm{~m}^{2}\right)$ and Foz do Iguaçu $\left(11.8 \mathrm{~m}^{2}\right)$. Figure 2 shows the complete map.

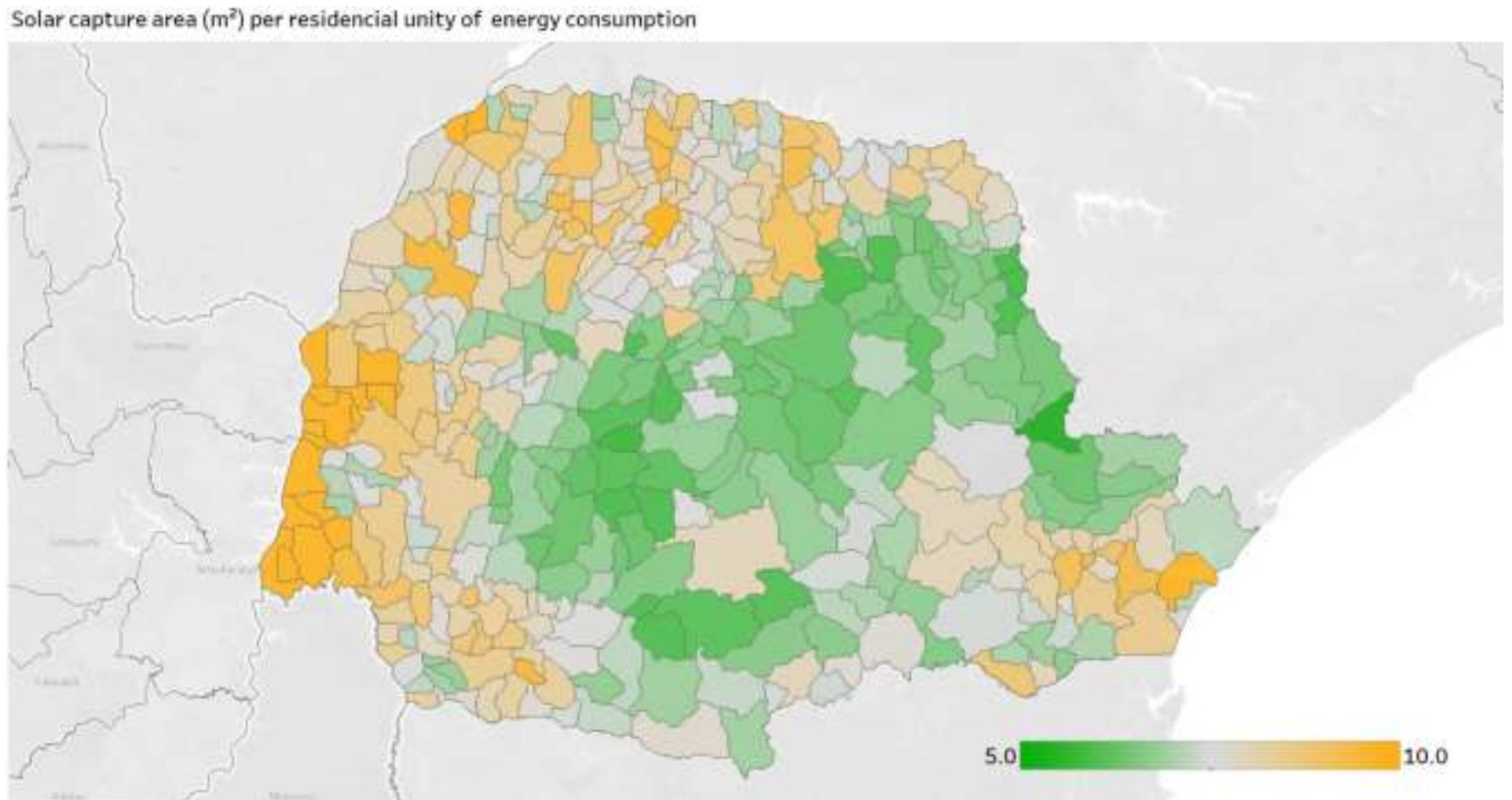

Figure 2. Required solar capture area $\left(\mathrm{m}^{2}\right)$ per residential unity of energy consumption for the supply of public electric power for each municipality of Paraná $[5,6]$. 


\section{Generation from biomass from agriculture wastes}

There is a critical issue about the use of agricultural wastes to generate energy in Brazil. Soil covering with the straws of several crops is essential to keep up both nutrients and the ecosystem, as well as the substrate permeability by reducing soil temperature variations and erosion losses. Other benefits are retaining more water and promoting larger crop yields, in addition to reducing water evaporation and runoff, which raises infiltration rates. Thus, the straw cover is essential for the sustainable management of the agricultural soil throughout the harvests [27].

This explains why just a few producers in Paraná have now managed to meet the recommended minimum levels of soil covering with crop wastes. Therefore, straw and branches of the largest crops of Paraná (sugarcane, corn, soybean, cassava, beans and wheat) cannot be considered sources of biomass for burning [28].

Presently, the sugar-alcohol sector explore intensively the sugarcane bagasse for cogeneration of energy through its burning. Thus, its potential is almost fully explored [29]. Corncob is another residue produced in large volume but it is important as a supplement in animal food formulations. Therefore, it is not available for burning [30,31].

In this analysis, the only crop biomass that showed some potential for burning was rice. As it is a flooded area crop, there is no need to keep the straw in the soil, so it is available for power generation. While the total State potential is $404 \mathrm{GWh} /$ year, most of this potential is concentrated in a few municipalities, all from the northwestern region of the State. This region could explore a potential around $389 \mathrm{GWh} /$ year through mini generation whilst $273 \mathrm{GWh} / \mathrm{year}$ is viable through distributed generation. Among these municipalities, five individually have potential for their own DG plants based on the burning of rice husk biomass. However, to reduce the total investment in infrastructure, it would probably be possible to install just one plant that gathers all the biomass generated, since the logistical costs would be relatively small due to the region concentrating more than $85 \%$ of the State's potential in a circular area of radius less than $50 \mathrm{~km}$ away.

Figure 3 shows that there is a great increase in energy potential, proportional to the size of rice crops in the few municipalities of the northwestern region, from 2000 to 2011. The State total potential shows a slight downward trend while the DG potential exhibits a stabilization, despite very much decline in 2016 with a recovery in 2017. This comparison shows a significant and gradual concentration of the potential, initially more dispersed in the State, in the few municipalities. Calculation of the statistical forecasts used historic data from 1980.

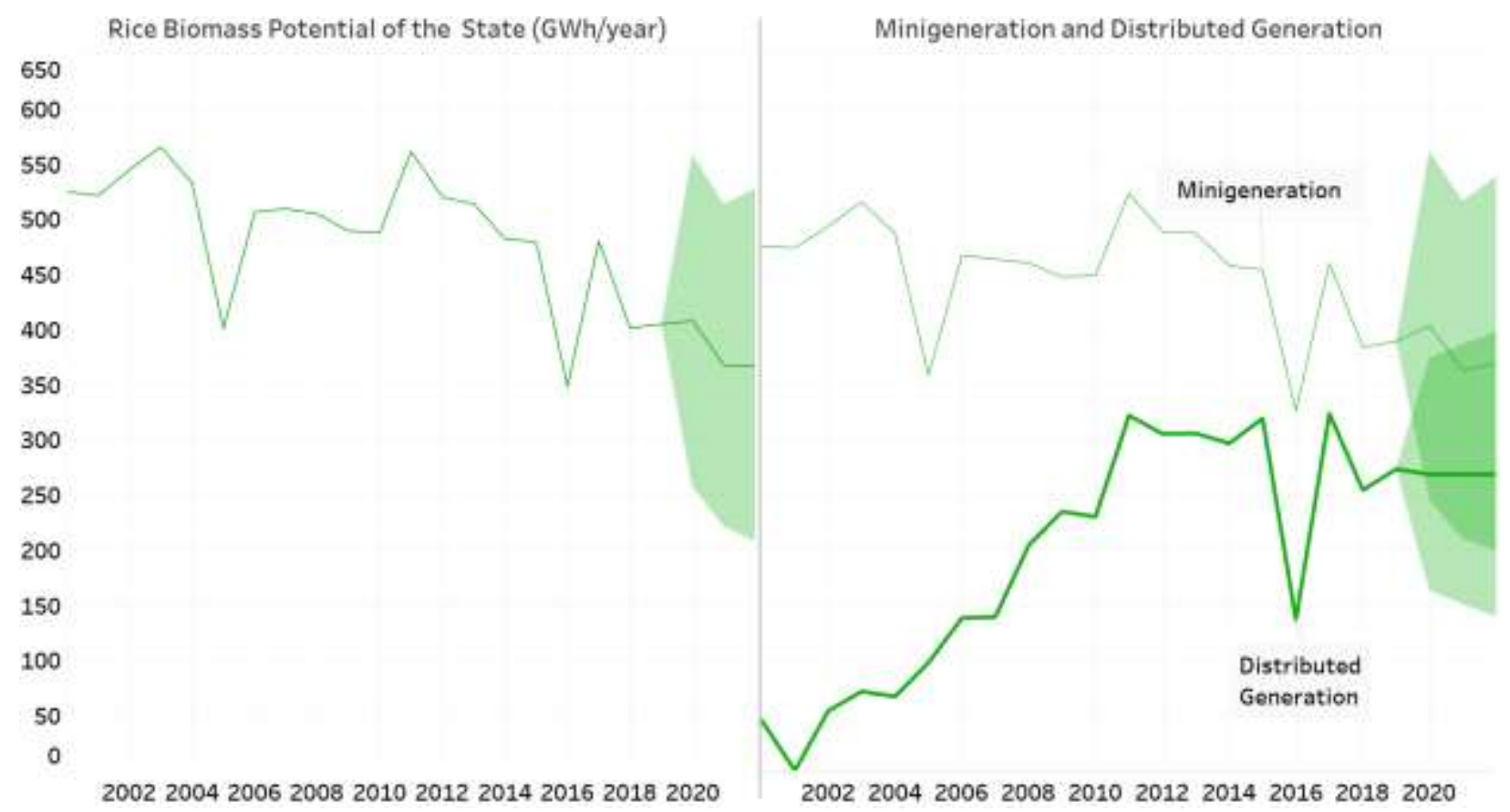

Figure 3. Comparison of the historical potential (GWh/year) of the entire state (left) for the biomass from rice hulls with the potential of the regions where mini generation (thin line on the right side) and distributed generation (thick line on the right side) are practical $[5,6]$. 


\section{Generation from biogas from the biodigestion of cassava starch wastewater}

We also appraised the hypothesis of using the energy produced with the biogas resulting from the biodigestion of cassava starch wastewater. Cassava wastewater (manipueira in Portuguese) is the milky liquid extracted by pressing the roots. It is poisonous due to the high content of hydrocyanic acid. Low values were found for the energy potential of the manipueira, as it generates only $4.1 \mathrm{~m}^{3}$ of biogas per $\mathrm{m}^{3}$ of this liquid residue [32,33].

For comparative purposes, the accumulated potential of this generation route is $2 \mathrm{GWh} / \mathrm{year}$, while that of rice straw is $349 \mathrm{GWh} /$ year. Therefore, the use of the manipueira for energy generation is infeasible in large scales. However, microgeneration is the best solution for the cassava producer in specific cases, considering a proper disposal of the liquid for animal feed or as a pesticide [34].

\section{Generation from biomass from forestry wastes}

Biomass wastes from paper and pulp processing (bark, twigs) and sawmills wood processing wastes (sawdust, chips, etc.) were separately examined.

It could be observed that the great potential of energy generation using pulp and paper wastes is already being used by Klabin S.A. industry, in the municipality of Telêmaco Borba. The company consumes the large area planted with pine and eucalyptus for energy cogeneration, which is directed to its industrial processes, including the use of black liquor, not considered in this analysis. The installed capacity of the black liquor plants is $3,883 \mathrm{GWh} /$ year.

Also, there are already seven forestry biomass based plants operating in the State and their energy generation capacity is equal to $620 \mathrm{GWh} /$ year.

The Furniture Industry has a potential of 1,691 GWh/year and the Pulp and Paper Industry presents $629 \mathrm{GWh} /$ year, disregarding the areas of Klabin. These potentials are mainly concentrated in the southeastern and central eastern regions of the State. Considering both sources and disregarding the operating capacity of the existing plants, it is available to explore about $1,700 \mathrm{GWh} / \mathrm{year}$ by mini generation initiatives. In theory, the practical potential for distributed generation is only $48 \mathrm{GWh} /$ year, which is about the minimal installation capacity of a DG plant. As this available potential is dispersed throughout large areas is safe to assume new DG plants based on forestry wastes are probably unviable in Paraná, at least in short terms.

Figure 4 illustrates the history and prediction up to 2022 of the energy potentials (GWh/year) of forest and wood wastes from furniture and pulp and paper industries in Paraná. Proportionally to the planted forest areas, the generating potential has a strong tendency to increase over time. The mini and distributed generation chart (right of Figure 4) disregards Klabin areas and, mainly due to this factor, the available potential of forest wastes from paper and pulp industry is considerably reduced, emphasizing the significant participation of the company in the total potential of the State.

It is clear that most of the available distributed generation potential comes from forests intended to the furniture industry. Another detail that can be highlighted in Figure 4 is that the potential values for DG have always been much lower than those for mini generation, a fact that is explained by the existence of many municipalities capable of enabling mini generation plants, however few of them with the potential for DG. Statistical forecasts come from historical data from 1984 on. 


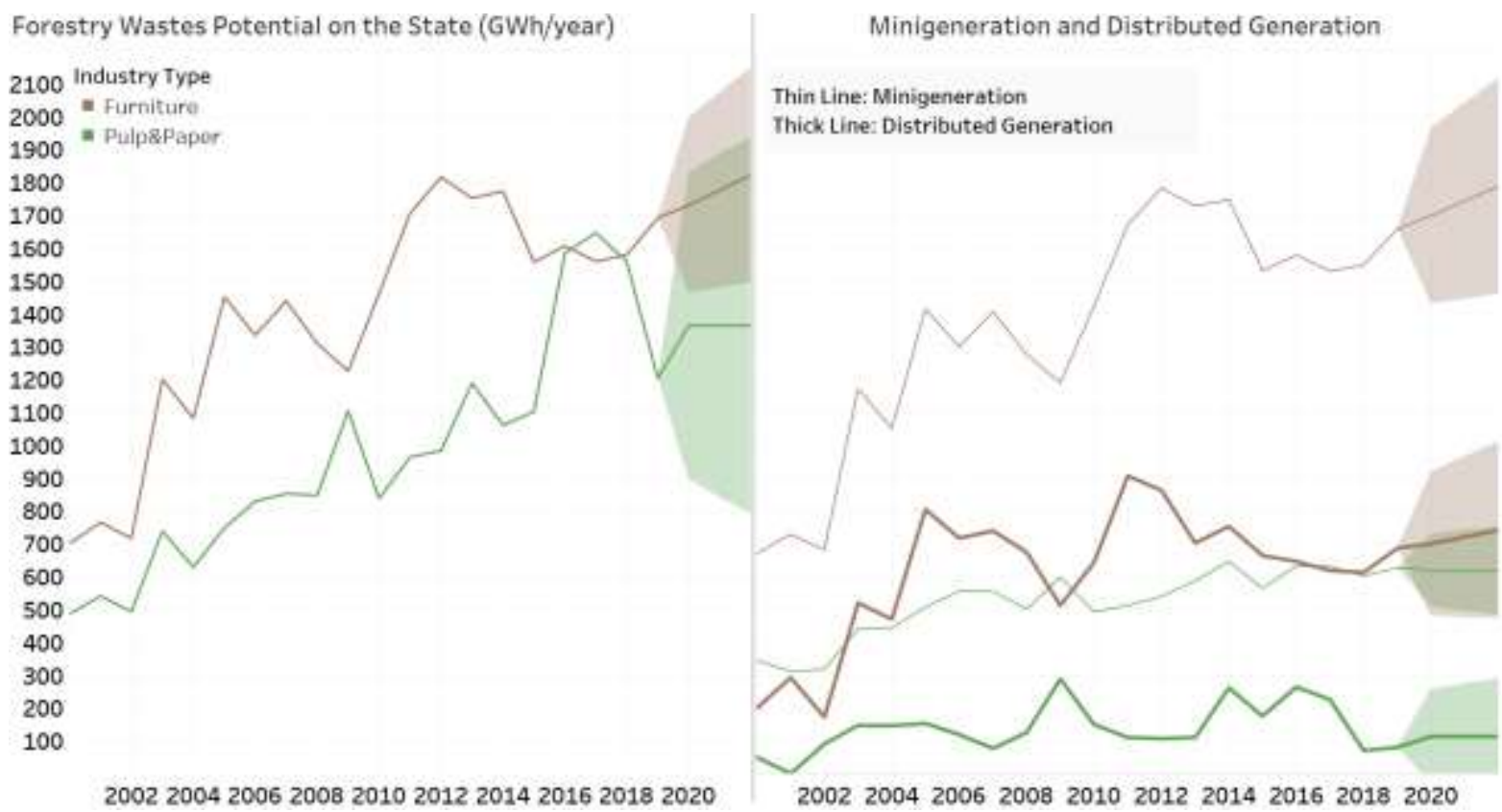

Figure 4. Comparison of the historical potential (GWh/year) of the entire state (left) for the biomass from forestry wastes with the potential of the regions where mini generation (thin line on the right side) and distributed generation (thick line on the right side) are viable $[5,6]$.

However, before any major decision based on this information, the recommendation is to check the real existence and availability of such excess wastes for burning. After all, there is a possibility that private boilers are burning those wastes or that companies are trending them as wood pellets, without being perceived through open data.

\section{Generation from biogas produced from animal breeding wastes}

We raised the production of wastes from three large Paraná cattle farms (chickens, pigs and milking cows) to find their potentials for generating energy using biogas. Biogas comes from biodigestion of the solid wastes excreted by chickens and pigs and whey (serum phase) of milk produced by cows.

As seen, the potential of milked cow wastes is more geographically scattered and the logistical costs would probably make any distributed generation plants unfeasible. Therefore, many municipalities could explore this potential individually through mini and microgeneration initiatives. The total estimated energy potential for the State is $269 \mathrm{GW} / \mathrm{h}$ and, if limited to the mini generation, it would be $197 \mathrm{GW} / \mathrm{h}$.

The total generation potentials of chickens and pigs wastes are around 1,219 and $530 \mathrm{GWh} /$ year, respectively. However, considering only the municipalities that have potential for mini generation, we have an added potential of 1,172 GWh/year and $478 \mathrm{GWh} /$ year for chickens and pigs, respectively, concentrated in the West and North regions of the State. In the same regions, some municipalities showed potential for distributed generation, totaling $53 \mathrm{GWh} /$ year and $91 \mathrm{GWh} /$ year for chickens and pigs, respectively. Taken together, the biogas plants based on animal wastes already installed in Paraná have an energy capacity of around $3.4 \mathrm{GWh} /$ year, representing only $0.18 \%$ of the potential identified for mini generation.

Figure 5 also shows a clear up trend for the energy potentials proportional to the number of animal units in the State, for wastes of the three species. Growth is even more prominent for chickens and pigs, as the statistical forecast shows probable increases in the order of $14 \%$ and $10 \%$, respectively, in the size of the farms, from 2019 to 2022. Few municipalities showed an individual capacity for the installation of a DG plant. Data from the historical series of animal units of each species in Paraná from 1980 was the base for the statistical predictions. 


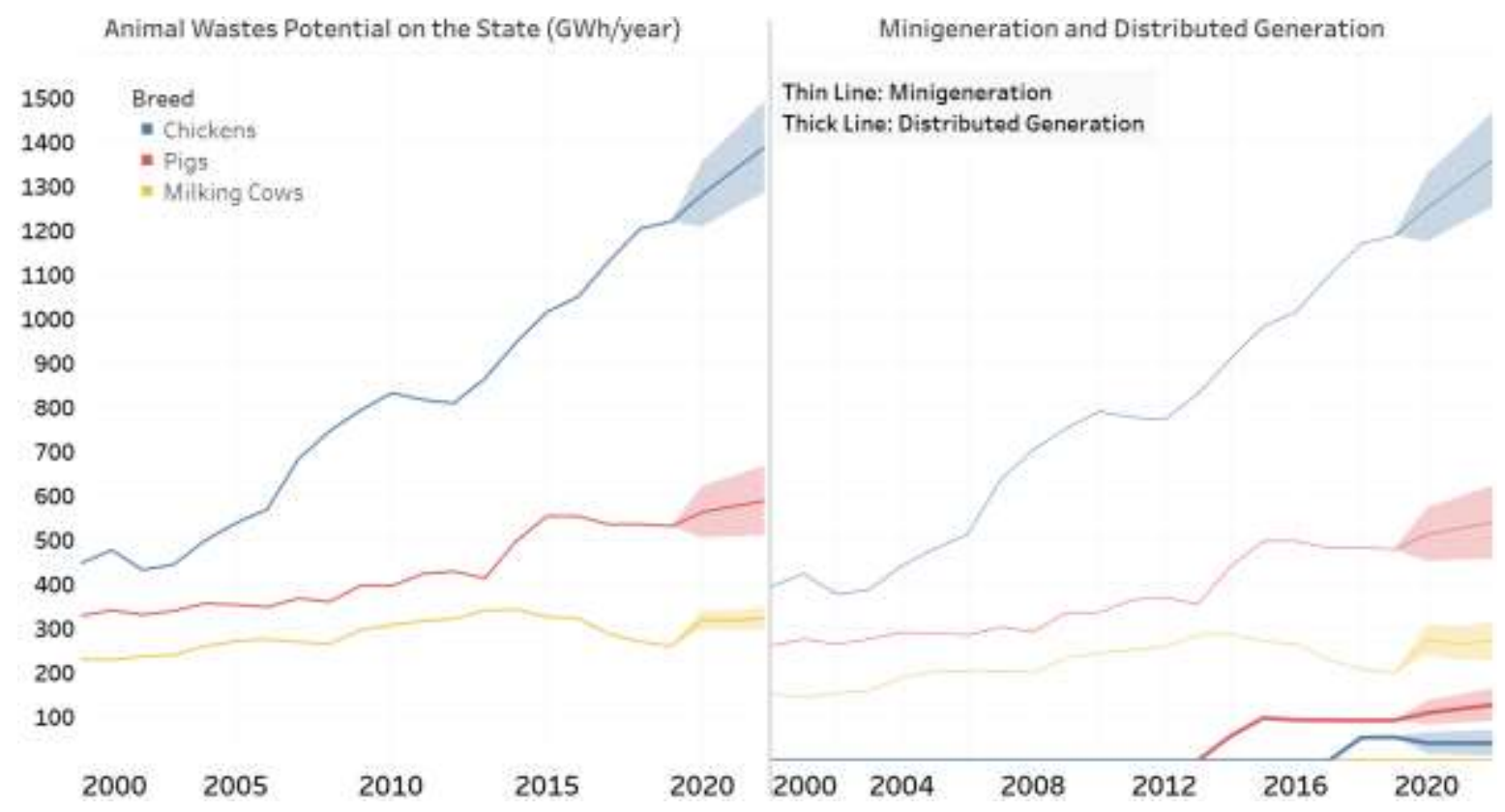

Figure 5. Comparison of the historical potential (GWh/year) of the entire State (left) for the biogas from chicken, pigs and milking cows wastes with the potential of the regions where mini generation (thin line on the right side) and distributed generation (thick line on the right side) are viable [5,6].

Schneider and coauthors (2011) report problems on the use of chicken wastes to generate biogas. Different materials compose the poultry bedding, such as sawdust, wood shavings, sugarcane bagasse or other materials available in the region. The authors affirm that biodigesters present difficulties on the biodigestion of the mixes between these bedding materials and bird wastes [16]. For this reason, this analysis considered the biodigestion of chicken waste isolated from the bedding materials. At the same time, its use as biomass can also bring obstacles due to the high humidity of the residues (this work does not evaluate such alternative). This operational limitation needs urgent technical solutions as it can discourage poultry farmers from reusing the wastes. Despite these obstacles, a biogas plant based on chicken wastes is successfully operating in the municipality of Matelândia.

Thus, it is worth remembering that the correct destination of these wastes is important and would not only have an impact on the energy matrix of Paraná, but also an extremely positive environmental impact.

It is proper to stress that the transportation and collection of these wastes to energy plants can present challenges, as the occurrence of these materials is over large areas. Therefore, incentives to microgeneration and mini generation would be very coherent to make possible the use of this potential in a decentralized and autonomous way. Reports such as "Opportunities of the biogas production chain for the state of Paraná" [35] are welcome initiatives to disseminate and demystify this generation model. Reduction of taxes and existence of incentives to the market of biodigesters and related equipment is also essential to enable generation of biogas by small and medium producers.

\section{Generation from biogas produced from municipal solid wastes}

The work also verified the potential of energy generation through biogas produced by biodigestion of municipal solid wastes (MSW).

The municipalities that presented the greatest potential of use of such energy source are those with the greatest population densities, as the generation scale of MSW is directly dependent on the size of the population of a locality.

The generation potential using municipal wastes (MW) is limited to big cities as they have better waste collection systems and are able to dispose larger volumes of waste daily. The generation potential using municipal wastes (MW) is limited to big cities as they have better waste collection systems and are able to dispose larger volumes of waste daily. To make the process possible, a daily intake of at least $150 \mathrm{t} /$ day is necessary, and 250 t/day is more convenient. This corroborates the assertion that there is a great viability with the scale of the process [23]. However, Johannessen (1999) [36] states that this minimum value should be $200 \mathrm{t}$ /day. Based on the minimum value of $200 \mathrm{t} /$ day and taking as a reference the average value of waste 
generation per inhabitant per day of $0.749 \mathrm{~kg}$ of MSW [22], only cities with about 250 thousand inhabitants could make the process viable.

Using this last criterion to determine the municipalities with the potential for distributed generation, only six municipalities in Paraná had such viability in 2010. In addition to the six municipalities, we also highlighted São José dos Pinhais for having more than 250 thousand urban inhabitants estimated for 2019. We calculated the potentials based on data from 2010, which was the year of the last housing census in which data on the urban mesh area and the urban population at the municipal level are available. Table 2 shows the absolute and by area potentials of urban mesh of the municipalities that demonstrated this viability.

Table 2. Energy potentials, absolute and by urban mesh area, of the MSW of the municipalities of Paraná with more than 250 thousand inhabitants, in 2010, and absolute potentials of the same municipalities estimated for 2019.

\begin{tabular}{lccc} 
Municipality & $\begin{array}{c}\mathbf{2 0 1 0} \text { Potential } \\
\text { (GWh/year) }\end{array}$ & $\begin{array}{c}\mathbf{2 0 1 0} \text { Potential/Area } \\
\text { (MWh/year/km } \mathbf{~})\end{array}$ & $\begin{array}{c}\mathbf{2 0 1 9} \text { Potential } \\
\text { (GWh/year) }\end{array}$ \\
\hline Curitiba & 54.6 & 126.8 & 60.2 \\
Londrina & 15.4 & 63.1 & 17.3 \\
Maringá & 10.9 & 84.1 & 13.0 \\
Ponta Grossa & 9.5 & 47.1 & 10.7 \\
Cascavel & 8.4 & 82.6 & 9.7 \\
Foz do Iguaçu & 7.9 & 48.3 & 8.0 \\
São José dos Pinhais & 7.4 & 90.5 & 9.0 \\
Total & $\mathbf{1 1 4 . 1}$ & & $\mathbf{1 2 7 . 8}$ \\
\hline
\end{tabular}

There were small municipalities with potential densities $\left(\mathrm{MWh} / \mathrm{year} / \mathrm{km}^{2}\right)$ even higher than the six considered viable, in 2010. However, they have populations of around 10,000 inhabitants, a value well below that recommended for making large scale distributed generation feasible. However, the improvement of infrastructure for the collection and transport of solid urban waste in these small cities may perhaps make it possible to take advantage of it through initiatives of mini or distributed microgeneration.

Figure 6 presents the history of the energy potential of MSW across the State and of mini generation in the largest urban centers in Paraná. The figures follow the population growth of the municipalities. We considered that by the year 2019 the urban populations of the six municipalities, which make MSW mini generation viable, have grown proportionally to the total population of the municipality. In view of the strong urbanization trends, we had a conservative estimate of the increase in populations in cities. Based on this assumption, we can estimate the minimum potential that each municipality had in 2019 (Table 2). It is also possible to estimate that the total potential of the State in the same year is $305 \mathrm{GWh} /$ year.

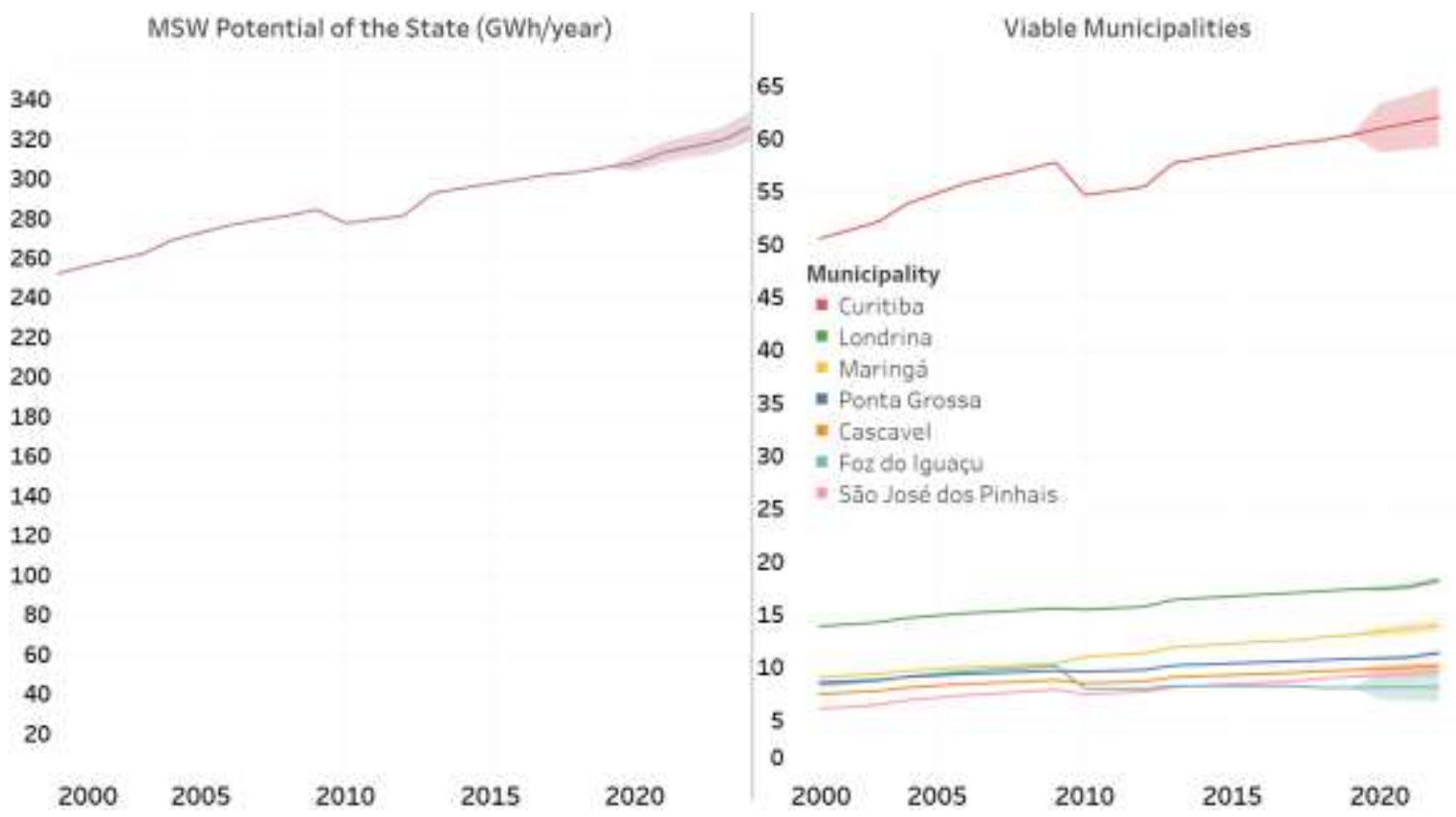

Figure 6. History and forecasts of the total energy potential (GWh/year) and of biogas distributed generation using municipal wastes in the largest urbanized regions of Paraná $[5,6]$. 
Currently, there is only one MSW biogas plant located in the municipality of Fazenda Rio Grande in the metropolitan region of Curitiba. This plant has an installed energy potential of $37.5 \mathrm{GWh} /$ year, which corresponds to about $54 \%$ of the estimated potential of the MSW in the urban centers of Curitiba and São José dos Pinhais in 2019.

\section{Overview and comparison between potential biomass and biogas sources}

As to compare all biomass and biogas sources discussed, Figure 7 compiles the total energy potentials and the distributed mini and distributed generation energy availability of each modality.

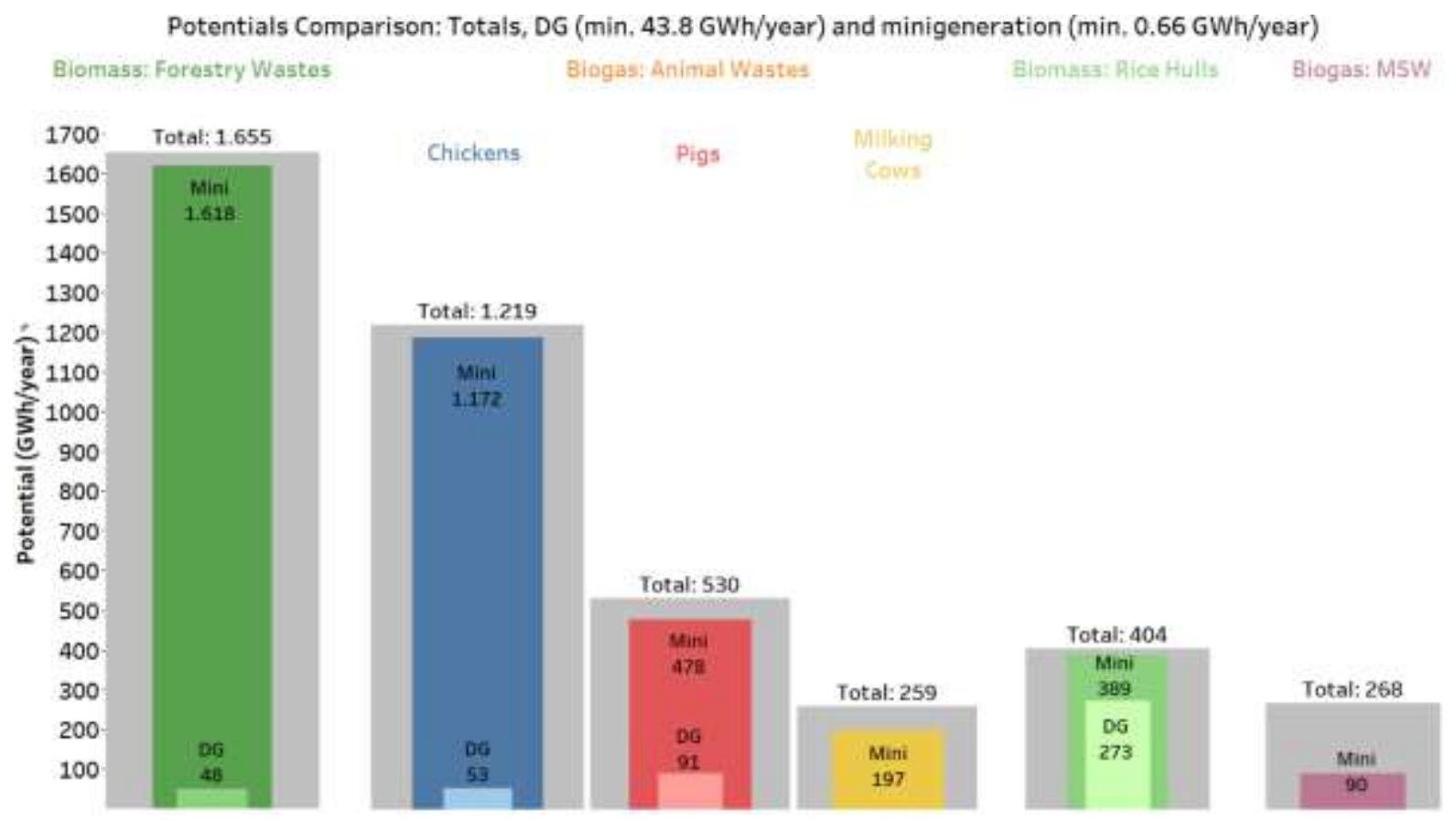

Figure 7. Comparison of Paraná total energy potentials (grey bars), mini generation (darker colored bars) and distributed generation (inner lighter colored bars) through the burning of biomass and biogas in 2019.

Clearly, the energy source that presented the highest estimated and usable potential is that of forest residues. Despite the disregard of the already explored forestry areas and of the already operating energy plants, the available potential for mini generation is still the highest among other appraised sources. Although, the forestry wastes have one of lowest distributed generation potentials representing only about $3 \%$ of the total available for this kind of waste in the entire State.

Despite the technical issues on exploring the poultry wastes, the total identified energy potential for the mini generation based on isolated chicken wastes is the second highest. The pig wastes also present high available energy generation potential. However, only one municipality individually presented potential for DG for each type of waste: Cascavel and Toledo could produce 53 and $91 \mathrm{GWh} /$ year through chicken and pig wastes, respectively. Although, the distributed generation potential of the pig waste is more concentrated, it represents $24 \%$ of the total estimated for the State.

In the case of milking cows, the wastes are dispersed in a large area of the State and prevent DG initiatives due to logistical cost limitations. However, it shows available potential for exploration through distributed micro or mini generation.

The absolute DG potential is the highest for rice crops residues, which is about $273 \mathrm{GWh} /$ year. It means that most of the State potential is highly concentrated in a few municipalities of the Northwest Region.

The estimated energy potential available for mini generation MSW is the lowest due to the limitation criteria regarding the population of the urban centers. Proportionally to the total State potential, its mini generation potential was also the lowest one reaching only $33 \%$ whilst the other energy sources reach at least $77 \%$ (wastes of milking cows).

The Figure 8 shows a comparison between the power generation potential mentioned above and the annual electric energy consumption in Paraná. In an optimistic scenario, considering the full potential of this first analysis, 4,335 GWh/year would be the possible annual energy production from biomass and biogas 
sources. It corresponds to about $21 \%$ of the electric energy consumed in Paraná in 2019, which was 20,367 GWh/year.

Considering only the amount available for mini generation and distributed generation, 3,944 and 465 GWh/year would be available for exploration, respectively. These values correspond to about $19 \%$ and $2 \%$, respectively, of the electricity consumed by the State in the same year.

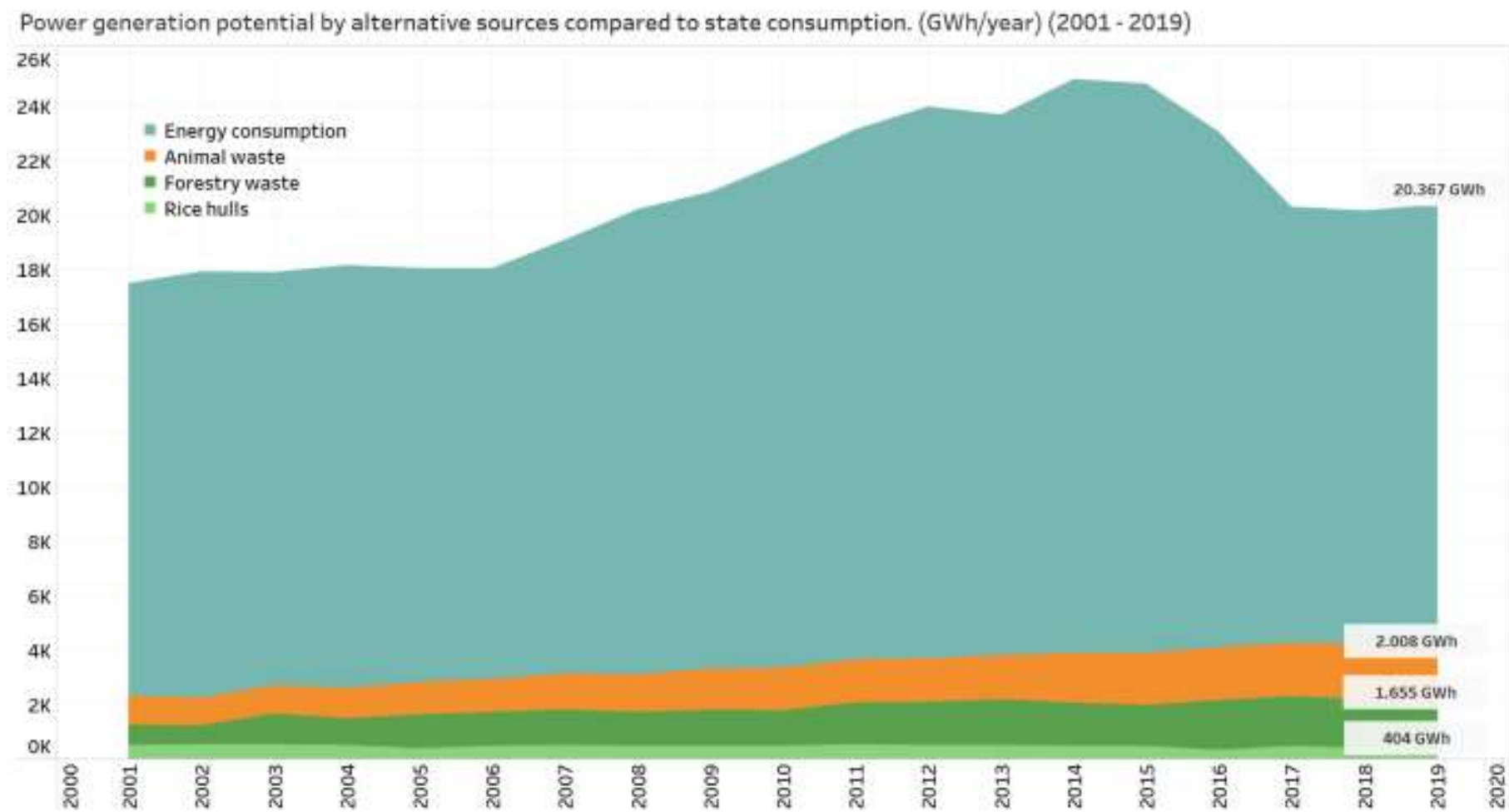

Figure 8. Power generation potential by alternative sources compared to state consumption. We omitted MWS from this chart because it does not appear properly due to the scales.

\section{CONCLUSION}

This work shows that all regions of the State have average annual levels of enough solar incidence for investment in electricity generation using photovoltaic plates. The solar incidence in Paraná is better than some countries in Europe, as seen in Figure 1, that have more state incentives than Brazil. The adoption of state tax incentives for the manufacture and import of photovoltaic and solar panels is essential to take advantage of this opportunity.

The exploration of milking cows (milk whey) and poultry wastes presents logistical and technical limitations. In relation to poultry wastes, they can contain several different materials used for bedding and high humidity, what undermines the process of anaerobic biodigestion used to produce biogas or the burning as biomass. Nonetheless, this work identified a high-energy generation potential for the isolated chicken wastes, as seen in figures 5 and 8.

Biogas is particularly important in the areas of the State with intensive pig rearing, as is the specific case of the Western Region. In this region, in addition to energy production, the incentive to a larger biogas generation would greatly contribute to mitigate the environmental impacts resulting from pig farming, still a problem not totally solved in Paraná.

The use of agricultural residues for energy generation comes down to the rice cultivation as the only viable culture to be explored without causing any further negative impacts on the quality of the soil and the next crops. The rice hulls present a potential still unexplored and a deep investigation is necessary for its effective use.

The use of biogas energy from urban solid waste requires a good waste collection system, as well as a high production rate. For this reason, the modality proved possible only in the seven largest urban centers of the State, as seen in Figure 6.

The harnessable energy potential in the State is very significant, reaching up to $19 \%$ of the electricity consumed by the grid in 2019. However, it is necessary to encourage the adoption of forms of distributed generation on smaller scales (micro and mini generation), as distributed generation on a larger scale is limited due to logistics costs. The use of this estimated potential for alternative energy sources brings benefits of 
diversification of the State's energy matrix and of highly positive environmental impacts due to better treatment of the agricultural, urban and industrial wastes.

This work does not exhaust the subject, but it provides important guidance so that the issue of alternative energies is properly addressed and developed in Paraná.

This work used open data and information available in the scientific literature as basis to produce the most precise estimate as possible about the scenario of alternative energy generation potentials in the State of Paraná. Therefore, a direct contact with the parties involved with the sources of interest must follow any decision based on this analysis.

Funding: This research received no external funding.

Acknowledgments: The authors thank TECPAR for the provided infrastructure and the Tableau Desktop licenses used for the required data analysis.

Conflicts of Interest: The authors declare no conflict of interest.

\section{REFERENCES}

1. Moreira L. Ribeirão do inferno - A primeira hidrelétrica do Brasil [Internet]. 2012 [cited 2017 Nov. 13]. Available from: http://revistaoe.com.br/ribeirao-do-inferno-a-primeira-hidreletrica-do-brasil/.

2. COPEL [Internet]. História da Energia no Paraná. 2020 [cited 2020 Oct. 9]. Available from: https://www.copel.com/hpcweb/educacao/historia-da-energia-no-parana/.

3. ANEEL [Internet]. Boletim de Informações Gerenciais - 4 Trimestre de 2018. 2018 [cited 2020 Oct. 8]. Available from:https://www.aneel.gov.br/documents/656877/14854008/Boletim+de+Informa\%C3\%A7\%C3\%B5es+Gerenciai s+-+4\%C2\%BA+trimestre+de+2018/36e91555-141a-637d-97b1-9f6946cc61b3.

4. Itaipu.gov. Energy. 2019 [cited 2020 Oct.]. Available from: https://www.itaipu.gov.br/en/energy/energy

5. IBGE [Internet]. Official website. 2020 [cited 2020 Sep.]. Available from: https://www.ibge.gov.br

6. IPARDES [Internet]. Official website. 2020 [cited 2020 Sep.]. Available from: http://www.ipardes.pr.gov.br

7. ANEEL [Internet]. Resolução Normativa № 482, de 17 de abril de 2012. 2020 [cited 2020 Sep. 28] Available from: http://www2.aneel.gov.br/cedoc/ren2012482.pdf

8. Pereira EB, Martins FR, Abreu SL, Ruther R. Atlas Brasileiro de Energia Solar - Base de Dados da Irradiação Global Horizontal, 2nd Ed [Internet]. São José dos Campos, SP. Brazil; 2017 [cited 2020 Sep.]. Available from: ftp://150.163.105.82/dados_publicos/atlas_2017/GLOBAL_HORIZONTAL_sedes-munic_(csv).zip

9. Souza SNM, Sordi A, Oliva CA. Potencial de energia primária de resíduos vegetais no Paraná. 4ํㅡㄹ Encontro de Energia no Meio Rural. Campinas, SP. Brazil; 2002.

10.Bazzo E, Bzuneck M, Miyake RG, Restrepo A, Kleveston F, Caneschi MD, Felippe L, Gomes ER, Dalsasso CH. Resultados da utilização de palha de arroz em processo de co-firing com carvão pulverizado. Anais do VII Congresso de Inovação Tecnológica em Energia Elétrica (VII CITENEL). Rio de Janeiro, RJ. Brazil; 2013 Aug 5-7. p. 1-8.

11.Koopmans A, Koppejan J. Agricultural and Forest Residues - Generation, utilization and availability. FAO Proceedings of the Regional Expert Consultation on Modern Applications of Biomass Energy. Bangkok. Thailand. 1998. p. 2-23.

12.Garcia AP. Eficiência de Combustão em Caldeiras Aquatubolares da Usina Odebrecht Alto Taquari. Especialize Online, IPOG 13th ed. [Internet]. Goiânia, GO. Brazil. 2017 Jul; 1(13). Available from: https://www.studocu.com/enus/document/multnomah-university/biomassa/tutorial-work/eficiencia-de-combustao-em-caldeiras-aquatubolaresda-usina-odebrecht-alto-taquari/5326938/view.

13.SUFRAMA [Internet]. Projeto Potencialidades Regionais - Estudo de Viabilidade Econômica: Amido de mandioca. Instituto Superior de Administração e Economia ISAE/Fundação Getúlio Vargas (FGV). Manaus, AM. Brazil. 2003 [cited 2020 Sep]. Available from: http://www.suframa.gov.br/publicacoes/proj_pot_regionais/amido.pdf

14.Cereda, MP (coord): Manejo, Uso e Tratamento de Subprodutos da Industrialização da Mandioca V. 4. São Paulo (SP): Fundação Cargill; 2001. 320 p.

15.Sganzerla E. Biodigestor: uma solução. Porto Alegre (RS): Agropecuária, 1983. 88 p.

16.Schneider VE, Peresin D, Trentin AC, Bortolin TA, Sambuichi RHR. Diagnóstico dos resíduos orgânicos do setor agrossilvopastoril e agroindústrias associadas. Brasília: Instituto de Pesquisa Econômica Aplicada (IPEA) [Internet]. 2012; 134p. [cited 2020 Sep]. Available from: https://www.ipea.gov.br/portal/images/stories/PDFs/ relatoriopesquisa/120917_relatorio_residuos_organicos.pdf

17. Nones DL, Brand MA, Ampessan CGM, Friederichs G. Biomassa residual agrícola e florestal na produção de compactados para geração de energia. Rev Cienc Agrovet [Internet]. 2017 [cited 2020 Sep]; 16(2): 155-64. Available from:https://www.revistas.udesc.br/index.php/agroveterinaria/article/download/223811711622017155/pdf/0 
18. Hillig E, Schneider VE, Weber C, Tecchio RD. Resíduos de madeira da indústria madeireira - caracterização e aproveitamento. XXVI ENEGEP [Internet]. 2006 Oct [cited 2020 Sep]; Fortaleza, CE, Brasil. Available From: http://www.abepro.org.br/biblioteca/ENEGEP2006_TR520346_8192.pdf.

19.Adetec.ind. Consumo de combustível. 2018 [cited 2018 Feb]. Available from: http://adetec.ind.br/consumo.asp

20. Oliveira PAV. Manual de manejo e utilização dos dejetos de suínos. Concórdia: EMBRAPA/CNPSA. 1993 [cited 2020 Sep]; 188 p. (document $\mathrm{n}$-27). Available from: https://www.embrapa.br/busca-de-publicacoes//publicacao/434003/manual-de-manejo-e-utilizacao-dos-dejetos-de-suinos

21. Kunz A, Oliveira PAV. Aproveitamento de dejetos de animais para geração de biogás. Revista de Política Agrícola. 2006 [cited 2014 Jun]; Ano XV - No 3. Available from: https://ainfo.cnptia.embrapa.br/digital/ bitstream/item/63324/1/Paginas-de-pol-agr-03-20064-p.-28-35.pdf.

22.ABRELPE. Panorama dos Resíduos Sólidos no Brasil 2013. 2014 [cited 2018 Feb 27]. Available from: http://www. abrelpe.org.br/Panorama/panorama2013.pdf.

23.FEAM. Aproveitamento Energético de Resíduos Sólidos Urbanos: Guia de Orientações para Governos Municipais de Minas Gerais. Belo Horizonte. 2012 [cited 2018 Feb 27]; 163 p. Available from: http://www.resol.com.br/cartilhas/aproveitamento_energetico_de_rsu_guia_feam_\%282 \%29.pdf.

24.Reid G, Wynn G. The future of solar power in the United Kingdom. Energies [Internet]. 2015 [cited 2020 Sep];8(8):7818-7832.Available from: 282462936_The_Future_of_Solar_Power_in_the_United_Kingdom

25. Mackay DJC. Solar energy in the context of energy use, energy transportation and energy storage. Phil Trans $\mathrm{R}$ Soc A [Internet]. 2013 [cited 2020 Sep]. 371:20110431. Available from: https://royalsocietypublishing.org/ doi/full/10.1098/rsta.2011.0431

26.SOLARGIS [Internet]. Global Horizontal Irradiation on Europe. 2011 [cited 2020 Sep]. Available from: https://pt.wikipedia.org/wiki/Ficheiro:SolarGIS-Solar-map-Europe-en.png.

27. Torres JCR, Fabian AJ, Pereira MG, Andrioli I. Influência de plantas de cobertura na temperatura e umidade do solo na rotação milho-soja em plantio direto. R Bras Agrociência [Internet]. 2006 [cited 2020 Sep]; 12(1): 107-13. Available from: https://periodicos.ufpel.edu.br/ojs2/index.php/CAST/article/download/4498/3372.

28. Lorenzon AR. Interview given by the Agricultural Engineer of the Department of Sustainable Rural Development (DEAGRO) of the Paraná State Department of Agriculture and Supply (SEAB-PR). 2017 Dec 20; Curitiba, PR. Brazil.

29.ANEEL [Internet]. Energy generation by source type. 2017 [cited 2018 Feb 6]. Available from: http://www.aneel.gov.br/dados/geracao

30.Santos MSR. Estudo de pré-tratamentos de palha e sabugo de milho visando a produção de etanol $2 \mathrm{G}$ [master's thesis] [Internet]. Maceió (AL): Federal University of Alagoas; 2014 [cited 2020 Sep]. 75p. Available from: http://www.repositorio.ufal.br/handle/riufal/1204.

31.Rocha MSRS, Almeida RMRG, da Cruz AJG. Avaliação do potencial energético de resíduos agroindustriais provenientes de diferentes regiões brasileiras. Engevista [Internet]. 2017 Jan [cited 2020 Sep]; 19(1): 217-235. Available from: https://periodicos.uff.br/engevista/article/view/9098

32. Feiden A, Cereda MP. Potencial energético do biogás gerado no tratamento de águas residuárias de fecularias em sistema piloto de biodigestão anaeróbia com separação de fases. Energ Agr. 2003; 18(2): 54-66.

33. Kuczman O, Gomes SD, Tavares MHF, Torres DGB, Alcântara MS. Produção específica de biogás a partir de manipueira em reator de fase única. R Eng Agríc [Internet]. 2011 [cited 2020 Sep]; 31(1): 143-49. Available from: https://www.scielo.br/j/eagri/a/hC4WVRvhpHLgTVK5pkSvkfv/?lang=pt\&format=pdf

34. EMBRAPA [Internet]. Manipueira, um líquido precioso. 2011 [cited 2020 Oct 9]. Available from: https://www.embrapa.br/busca-de-noticias/-/noticia/18147209/manipueira-um-liquido-precioso?p_auth=glvdLAit

35.FIEP, SENAI/PR [Internet]. Oportunidades da cadeia produtiva de Biogás para o estado do Paraná 2016. 2016 [cited 2017 Dec]. Available from: http://www.fiepr.org.br/observatorios/download---oportunidades-da-cadeia-produtiva-debiogas-para-o-estado-do-parana-1-19295-319478.shtml

36. Johannessen LM. Working paper series - Guidance note on recuperation of landfill gas from municipal solid waste landfills [Internet]. Washington, D.C: The World Bank; 1999 [cited 2020 Oct 9]. Available from: http://documents1.worldbank.org/curated/en/892171468766767158/pdf/multi-page.pdf

(c) 2021 by the authors. Submitted for possible open access publication under the terms and conditions of the Creative Commons Attribution (CC BY NC) license (https://creativecommons.org/licenses/by-nc/4.0/). 